\title{
Strategic and sporadic marine consumption at the onset of the Neolithic: increasing temporal resolution in the isotope evidence
}

\author{
Janet Montgomery ${ }^{1}$, Julia Beaumont ${ }^{2}$, Mandy Jay ${ }^{1,2,3}$, Katie Keefe ${ }^{4}$, \\ Andrew R. Gledhill ${ }^{2}$, Gordon T. Cook ${ }^{5}$, Stephen J. Dockrill ${ }^{2} \&$ \\ Nigel D. Melton ${ }^{1,2}$
}

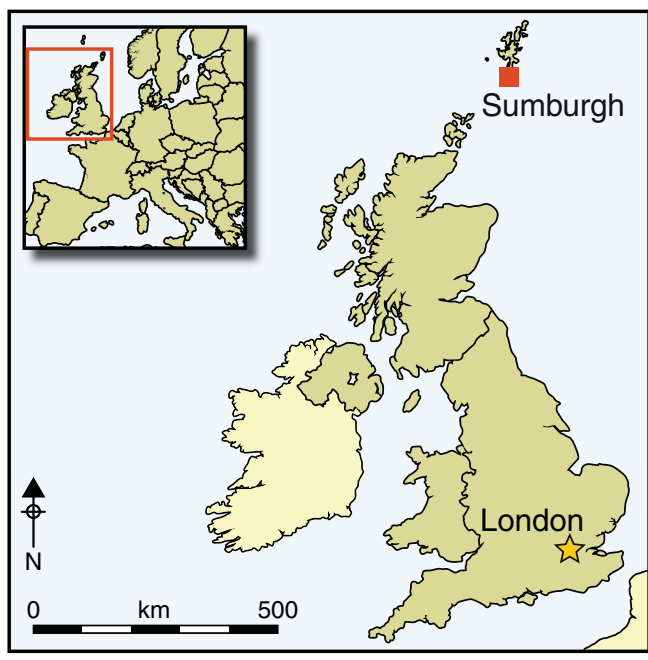

Stable isotope analysis has provided crucial new insights into dietary change at the Neolithic transition in north-west Europe, indicating an unexpectedly sudden and radical shift from marine to terrestrial resources in coastal and island locations. Investigations of early Neolithic skeletal material from Sumburgh on Shetland, at the far-flung margins of the Neolithic world, suggest that this general pattern may mask significant subtle detail. Analysis of juvenile dentine reveals the consumption of marine foods on an occasional basis. This suggests that marine foods may have been consumed as a crucial supplementary resource in times of famine, when the newly introduced cereal crops failed to cope with the demanding climate of Shetland. This isotopic evidence is consistent with the presence of marine food debris in contemporary middens. The occasional and contingent nature of marine food consumption underlines how, even on Shetland, the shift from marine to terrestrial diet was a key element in the Neolithic transition.

Keywords: Shetland, Mesolithic-Neolithic transition, marine consumption, stable isotopes, dentine, bone

Supplementary material, including Tables $\mathrm{S} 1-\mathrm{S} 5$ and Figure $\mathrm{S} 1$, is provided online at http://antiquity.ac.uk/projgall/montgomery338/

\footnotetext{
Department of Archaeology, Durham University, South Road, Durham DH1 3LE, UK

(Email: janet.montgomery@durham.ac.uk; author for correspondence)

Archaeological Sciences, School of Life Sciences, University of Bradford, Bradford BD7 1DP, UK

Department of Archaeology, University of Sheffield, Northgate House, West Street, Sheffield S1 4ET, UK

York Osteoarchaeology, Ivy Cottage, 75 Main Street, Bishop Wilton, York YO42 1SR, UK

Scottish Universities Environmental Research Centre, Rankine Avenue, East Kilbride G75 OQF, UK

(C) Antiquity Publications Ltd.

ANTIQUITY 87 (2013): 1060-1072

http://antiquity.ac.uk/ant/087/ant0871060.htm
} 


\section{Introduction}

Stable isotope analyses of Mesolithic and Neolithic human bone collagen from northern and western Europe have been reported to demonstrate a sharp shift away from the consumption of marine foods at the onset of the Neolithic (Tauber 1981; Richards et al. 2003). This has led to controversy over the apparent contradictions between the Neolithic archaeology and the isotope data, with part of the discussion being presented previously in Antiquity (Richards \& Mellars 1998; Schulting \& Richards 2002; Bailey \& Milner 2003; Hedges 2004; Milner et al. 2004; Richards \& Schulting 2006; Bonsall et al. 2009). Some coastal site middens contain thousands of marine ecofacts, suggesting that these resources must have played a significant part in the subsistence base, and the suggestion that this was not the case has also raised questions about why coastal dwellers would reject a readily available food resource in the early days of establishing agriculture, especially on marginal and remote islands. The previously published work has utilised adult human bulk bone collagen which provides an average of many years' diet and is thus a relatively blunt tool providing only blurred temporal focus (Hedges et al. 2007). In the research presented here we have used a new technique which utilises high-precision dentine increments, allowing us to increase temporal resolution and identify dietary patterns over very short periods of an individual's early life. Our findings hold significance not only for Neolithic Shetland, which has "remained something of an enigma” (Sheridan 2012: 6), but also for understanding how the first farmers in marginal regions across Atlantic Europe survived during periods of resource shortages and famine. The results also address the paradox between the mainly terrestrial dietary isotope ratios of humans and the continued presence of marine food remains at some Neolithic sites.

\section{A marginal environment for early farmers}

Our study uses material dating to the Mesolithic-Neolithic transition from the Shetland Islands: at $60^{\circ} \mathrm{N}$, these are the most northern Scottish islands in the North Atlantic (Figure 1) and an ideal place to test the hypothesis that marine resources would be included in the north-west European diet during this period if conditions were difficult. Even accounting for the Holocene hypsithermal, the climate would have been marginal for agricultural purposes and expected to generate periods of crop failure and famine (Birnie et al. 1993). According to the 'dietary shift' model, marine resources are proposed to have been abandoned by choice at the Mesolithic-Neolithic transition. The best place to confirm this is a coastal, marginal environment where there is every reason to believe that such resources would be key to survival.

The disarticulated remains of a minimum of 11 adults and 9 juveniles and infants (Walsh et al. 2012) were recovered from a stone-lined, sub-rectangular pit, a non-megalithic funerary monument of a type not previously suspected, that was uncovered during the 1977 construction works at Sumburgh Airport, at the southern tip of the archipelago (Hedges \& Parry 1980) (Figure 2). They are the only skeletal remains of the Early Neolithic inhabitants to be recovered from these islands. The importance of this area to the colonisation of the archipelago has been further demonstrated by a Late Mesolithic-Early Neolithic sequence of middens exposed by coastal erosion at West Voe, some $400 \mathrm{~m}$ to the south (Melton \& 


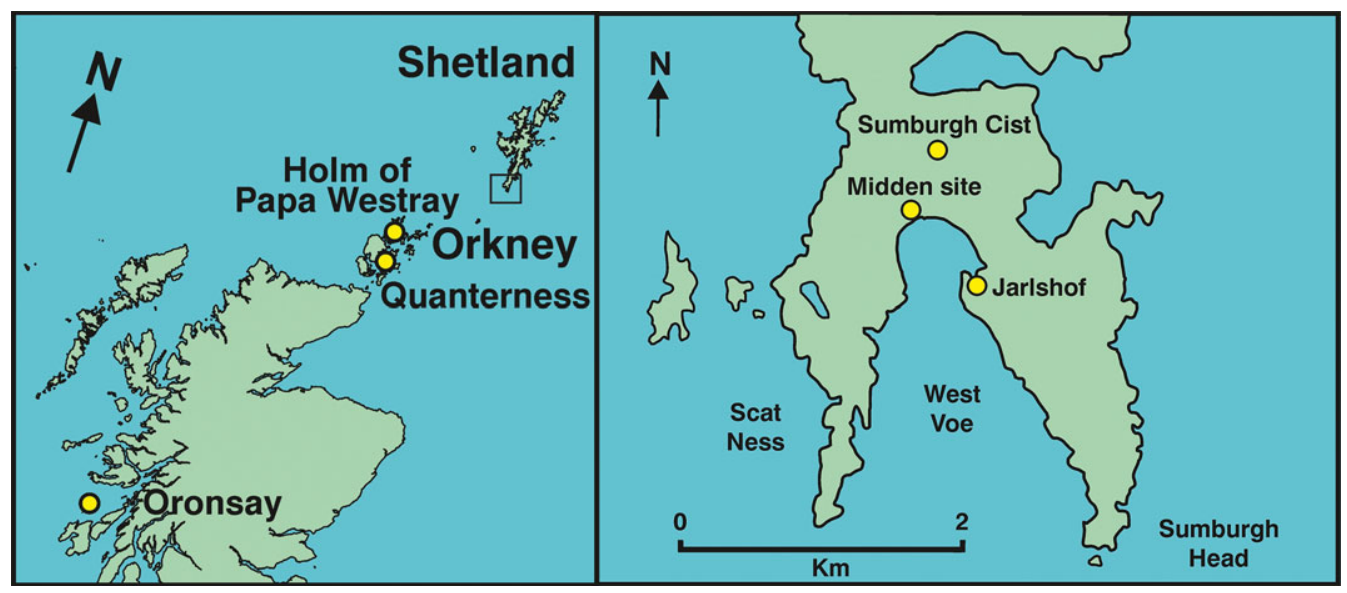

Figure 1. Map showing the Shetland and Orkney Islands in the North Atlantic and Oronsay on the west coast of Scotland (left); and the locations of Sumburgh, West Voe and Jarlshof on Shetland (right).

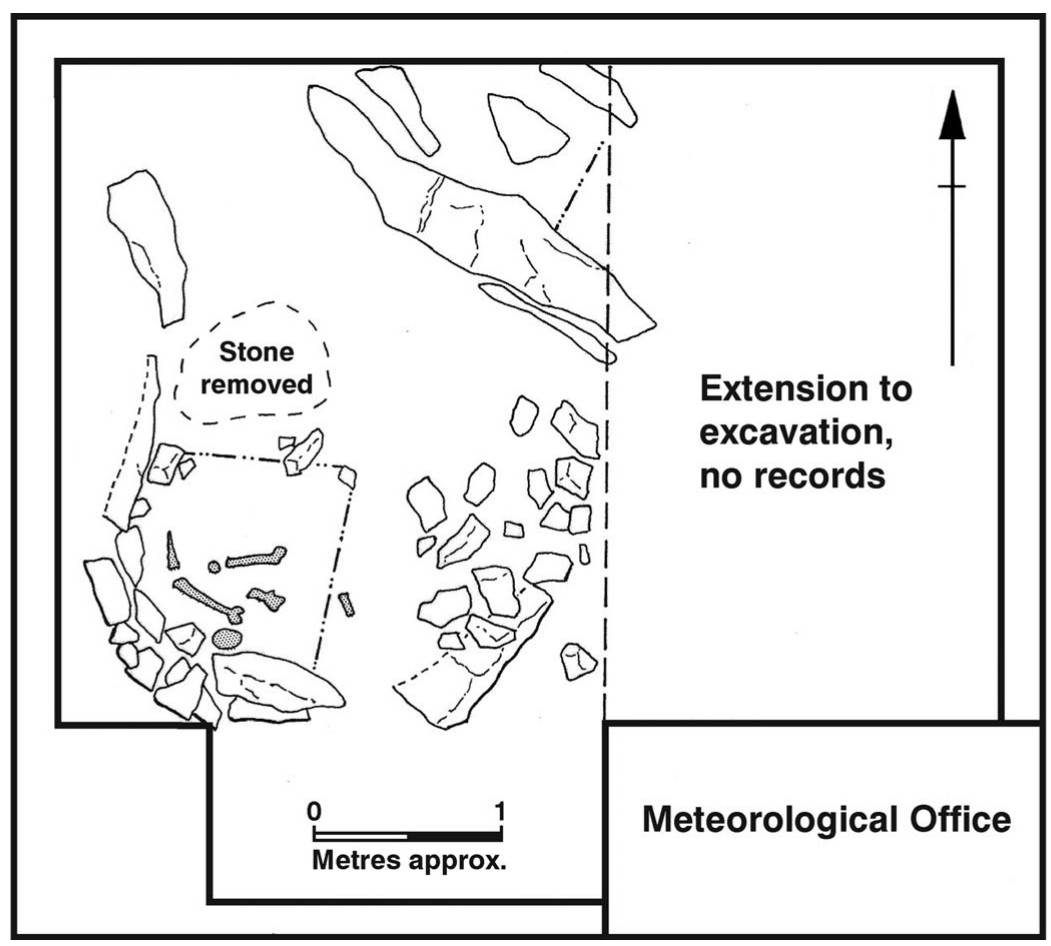

Figure 2. Plan of the cist at Sumburgh interpreted by N.D. Melton and S. Walsh from excavation photographs taken by G. Parry and archived at the RCAHMS. Human bones are identified by stippling.

Nicholson 2004, 2007; Melton 2009), and by recent investigations at the internationally renowned site of Jarlshof, on the opposite side of the voe (Dockrill \& Bond 2009) (Figure 1).

The human remains have been dated to between 3510 and 2660 BC (14 radiocarbon dates, calibrated taking into account a marine dietary component; details in Table S1). (C) Antiquity Publications Ltd. 
The two superimposed middens at West Voe are separated by a layer of sand and have been dated to $c$. 4300-3250 BC, the lower midden spanning the Mesolithic-Neolithic transition and the upper, which has provided dates of $c$. 3500-3250 BC, overlapping with the human remains found at Sumburgh. Mussels (Mytilus edulis), seals, seabirds and a few small fish were found in the uppermost layers of the lower midden together with sheep and cattle which predate the Sumburgh humans. The upper midden was composed entirely of cockles (Cerastoderma edule), many of which were shattered and discoloured from being heated, with continuing evidence for sheep and cattle in associated layers and contemporary with the human remains (Melton 2008, 2009). Together, they provide direct evidence for subsistence practices adopted by the earliest farmers, with the exploitation of marine resources (molluscs, fish, seals and seabirds) apparently continuing alongside the adoption of agriculture, represented by finds of cattle (confirmed by proteomics analysis, M. Buckley pers. comm.) and sheep bones. The recent investigations at Jarlshof have provided radiocarbon dates of 3770-3610 and 3640-3380 BC (both 95\% probability; SUERC-15163 \& 15123) from an oyster shell and a charred grain of six-row barley respectively, recovered from the earliest archaeological horizon. The dates indicate that this layer is equivalent to some of the earliest deposits in the West Voe midden sequence. The investment of labour to produce fertile soils, initially by a build-up of ash-rich midden material followed by organic additives, permits intensive arable production within small managed plots. These soils provide an inherited resource that can build in depth through time and be passed on to future generations; they also form a catalyst for sedentary living. The crop six-row barley has an added advantage as a commodity whose storable surplus in 'good years' might be used in times of famine. Resilience and sustainability demonstrated by the longevity of settlements could only be achieved at such times of yield shortage ('bad years') by the combined use of other resources within the mixed economy (Dockrill \& Bond 2009: 43-45). The archaeological evidence thus points to the existence of a mixed agricultural economy, supplemented by the exploitation of marine resources, at the time of the Sumburgh burials. The burials cut into a $0.5 \mathrm{~m}$ thick layer of storm sands which were deposited c. $3500 \mathrm{cal} \mathrm{BC}$. These sands separate the two middens at West Voe (Gillmore \& Melton 2011) and suggest that much of the local area had been inundated by sand just prior to the commencement of the interments at Sumburgh, increasing its agricultural marginality and necessitating the creation of anthrosols capable of cereal production.

\section{Carbon and nitrogen isotope data}

One of the most widespread uses of $\delta^{13} \mathrm{C}$ and $\delta^{15} \mathrm{~N}$ values (the ratios of ${ }^{13} \mathrm{C} /{ }^{12} \mathrm{C}$ and ${ }^{15} \mathrm{~N} /{ }^{14} \mathrm{~N}$ in a sample, relative to international standards) in the context of palaeodietary studies is to document the consumption levels of marine resources in prehistory. Marine food webs are significantly enriched in ${ }^{13} \mathrm{C}$ compared to those terrestrial resources which have a $\mathrm{C}_{3}$ photosynthetic pathway, while the effects of marine environments and trophic levels mean that consumers of marine resources will also show higher $\delta^{15} \mathrm{~N}$ values (LeeThorp 2008). The expectation for individuals with significant levels of such resources in their diet relative to those with purely terrestrial $\mathrm{C}_{3}$ diets is that both $\delta^{13} \mathrm{C}$ and $\delta^{15} \mathrm{~N}$ values

(C) Antiquity Publications Ltd. 
from their collagen extracts will be higher. In this study, no consideration of $\mathrm{C}_{4}$ terrestrial diets is required since such plants were not present in prehistoric Britain.

\section{The problem and the solution}

Existing isotope data suggest the abandonment of marine food consumption at the Mesolithic-Neolithic transition. Not only does the archaeological evidence sometimes appear to refute the isotope data, but it seems counterintuitive that the early farmers living at isolated and marginal coastal locations would completely abandon an easily obtained resource. A problem which has been difficult to address is that bulk bone collagen, which is the material usually investigated for the isotope analyses, reflects a weighted averaged diet over a long period of an individual's life (Hedges et al. 2007). This means that short periods of unusual consumption, such as might occur when marginal environments do not yield sufficient terrestrial resources (e.g. sporadic and unpredictable crop failure), will not be visible in the target tissue. For this study we have used three distinct skeletal collagen fractions with progressively finer temporal resolution: (1) bulk bone; (2) bulk dentine; and (3) small (c. $1 \mathrm{~mm} / 20 \mathrm{mg})$ incremental dentine samples. The collagen in primary dentine, unlike bone, does not remodel once mineralisation is complete, and the age at which human teeth begin to form and the duration of their growth has been well established (Hillson 2005; AlQahtani et al. 2010). New techniques for targeting small incremental dentine samples which have formed over periods of less than a year, as opposed to the larger increments covering several years (Fuller et al. 2003), allow a temporally focused study of an individual's diet in which short periods of marine consumption may be visible (Beaumont et al. 2013).

\section{Samples analysed}

Collagen was extracted from: (1) 12 bulk bone samples; (2) bulk samples of the root dentine of 17 permanent second molars; and (3) incremental dentine samples processed from a further eight teeth. Methods are described in Beaumont et al. (2013; Method 2 for incremental sampling) and samples are detailed in Table S2. Up to 21 incremental transverse samples from root apex to enamel-dentine junction were taken from each tooth in the third group. These increments span periods of formation, depending on the tooth involved, from just before birth up to 15 years. These three fractions therefore represent: (1) lifetime averaged diet; (2) childhood averaged diet; and (3) serial data for short periods of less than a year throughout childhood.

The composition of the primary dentine used in this study is, like enamel, determined largely at the time of formation (Rowles 1967; Veis 1989). Nevertheless, the cells of dentine, the odontoblasts, remain active, and formation of new, secondary dentine continues throughout life, in layers lining the pulp cavity (van Rensburg 1987; Hillson 2005). The presence of secondary dentine is used as an ageing technique and is rarely found in individuals below 30 years of age (Gustafson 1950). Further deposition of dentine mineral (as opposed to collagen) within the dentinal tubules may occur in the fourth decade of life, starting from the root tip and progressing at a relatively constant rate (Nanci 2003; Hillson 2005). Any change to dentine composition over time is, therefore, chiefly of an additive nature and will

(C) Antiquity Publications Ltd. 
be negligible in individuals under the age of 30 , such as those in this study (Table S2). As an extra precaution, all circumpulpal dentine was removed by reaming prior to demineralisation (Beaumont et al. 2013). Quality indicators for the processed samples are provided in Tables S3, S4 and S5 and all collagen, both from bone and dentine, fits well into the accepted ranges for atomic C:N ratios and percentages of carbon and nitrogen present (van Klinken 1999). The samples are, therefore, considered to be free of post-mortem contamination.

The disarticulated and commingled nature of the burial deposit means that it is not possible to directly associate bone samples with teeth. Whilst it is a possibility that the bone samples come from a group of individuals with dietary histories different from a second group represented only by the teeth samples, it is an exceptionally unlikely one: the osteological analysis of the material concluded that there were 11 adults and 9 juveniles or infants present, totalling 20 individuals (Walsh et al. 2012), whilst the sampled dental assemblage of 25 teeth represents a minimum number of 13 individuals (7 adults and 6 juveniles) (Table S2). Two of the juvenile bulk dentine samples (SUMB-5 and SUMB-11: upper and lower right second molars) may have come from the same individual, based on tooth development and similarity of isotope ratio data.

Mesolithic-Early Neolithic bone collagen data for terrestrial animals, seals and seabirds from West Voe and Sumburgh have also been obtained, together with modern Cerastoderma edule (cockle) flesh. The midden material suggests that cockles were available and used during the Neolithic, but the flesh is not preserved in the archaeological contexts. The modern proxies were collected in order to provide an estimate of their place in the food web, although the data obtained have not been adjusted for the fossil fuel effect (see online supplementary information).

\section{Results: bone collagen and bulk dentine collagen}

Figure 3 (using data from Tables S3 and S4) plots the Sumburgh bone and bulk dentine data separately (sample types (1) and (2)) with comparative Mesolithic and Neolithic human data published for other Scottish islands (Orkney Islands and Oronsay, see Figure 1). Also plotted are archaeological animal bone data from the West Voe middens and Sumburgh, together with the modern cockle flesh (see Table S4). The Mesolithic Oronsay humans are high-level marine resource consumers (plotting with the Neolithic marine-consuming animals), whilst the Neolithic Orkney Islands individuals are considered to have a mainly terrestrial diet (Schulting \& Richards 2009; Schulting et al. 2010). The highest $\delta^{13} \mathrm{C}$ value for the comparative Neolithic data sets $(-19.1 \%)$ is used as a conservative limit for a largely terrestrial diet. The diet in that case was interpreted as mainly terrestrial, although a small percentage of marine resources may have been present and this is one of many locations in Europe where the evidence seems to suggest a low level of such consumption which is not easily identified from the bulk stable isotope data (Lubell et al. 1994; Fischer et al. 2007; Eriksson et al. 2008; Bonsall et al. 2009; Smits et al. 2010). Those individuals with carbon isotope ratios more enriched in ${ }^{13} \mathrm{C}$ than this limit are seen to the right of the middle vertical line and it is these that are indicative of a marine component in the diet. Only one of the bone collagen samples falls to the right of the line together with 11 of the 25 bulk dentine data points which are enriched in both ${ }^{13} \mathrm{C}$ and ${ }^{15} \mathrm{~N}$. There is no correlation between the 

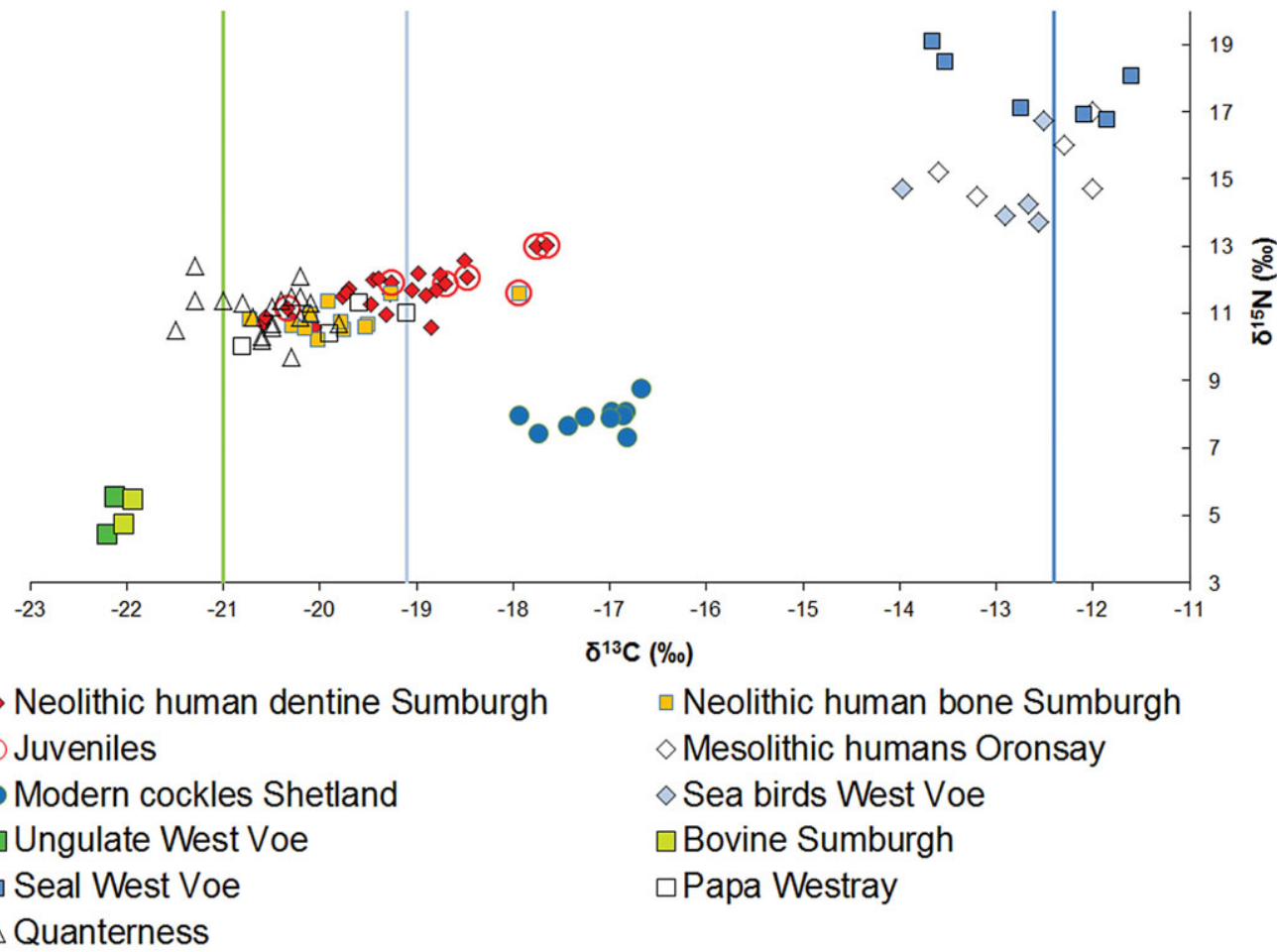

\section{O Juveniles
- Modern cockles Shetland $\square$ Ungulate West Voe $\square$ Seal West Voe $\triangle$ Quanterness

- Neolithic human dentine Sumburgh

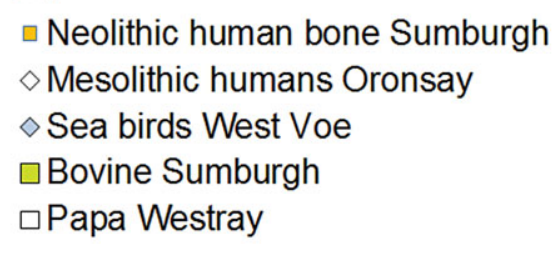

$\square$ Neolithic human bone Sumburgh

Sea birds West Voe

Sea birds West Voe

Papa Westray

Figure 3. Carbon and nitrogen stable isotope ratios for Sumburgh bone and bulk dentine, with comparative Scottish island Neolithic and Mesolithic data. Samples from Middle to Late Neolithic Quanterness (Schulting et al. 2010) and Holm of Papa Westray (Schulting \& Richards 2009) are all human bone; both sites are in Orkney. Mesolithic humans are from Oronsay (Richards \& Mellars 1998). The modern cockle muscle samples have not been adjusted for the Suess effect (see online supplementary information). The light blue vertical line represents the limit of the highest $\delta^{13} C$ value for the Orkney Neolithic material, a conservative estimate for the limit at which the diet might be considered mainly terrestrial. The dark blue and dark green lines are the estimates for 100 per cent marine and terrestrial diets respectively, as used for calibrating the radiocarbon dates (Table S1).

Sumburgh radiocarbon dates and the level of marine consumption (Figure 4) and thus no suggestion that the earliest Neolithic humans from this group relied more heavily on marine resources than those living there later in the period.

$\delta^{13} \mathrm{C}$ values are affected by local environmental conditions as well as dietary considerations. For this reason, comparisons are best made with data sets from the same region and this is why the Orkney Neolithic data have been shown here. End-members for terrestrial and marine diets have been empirically estimated at $-21.0 \%$ and $-12.4 \%$ o respectively and between these two extremes the upper boundary for terrestrial diets, the lighter blue line in Figure 3, as $-19.1 \%$. Terrestrial diets in the region, therefore, are conservatively deemed to range between the boundary value of $-19.1 \%$ and the terrestrial end-member (-21.0\%; the green line in Figure 3), discussed in the online supplementary material for the calibration of the radiocarbon dates. This upper boundary is used for illustration based on the interpretation of the geographically closest available data set for the time and place under discussion. It would not necessarily reflect a purely terrestrial diet in (C) Antiquity Publications Ltd. 


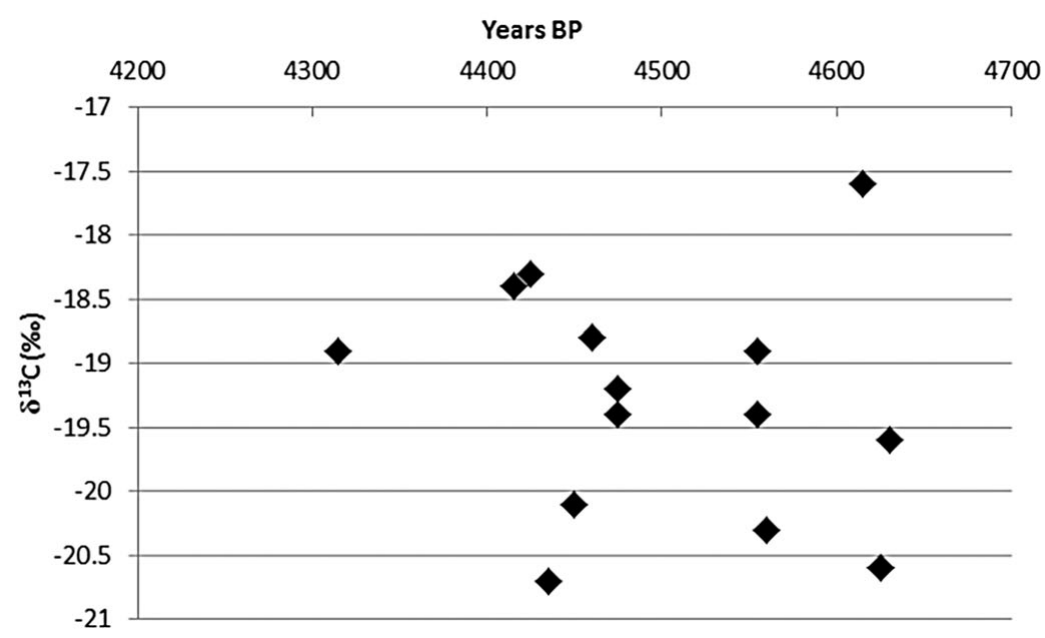

Figure 4. Carbon stable isotope ratios plotted against radiocarbon age BP for dated dentine samples (see Table S1 for dating details). There is no correlation between date and the higher $\delta^{13} C$ values, suggesting that marine consumption patterns do not change over time during this period.

north-west Europe, however, but more probably a low level of marine resource consumption at some time in an individual's life. A more likely boundary for a purely terrestrial diet in this region is $-20.0 \%$ (Bonsall et al. 2009). If that were used in this chart, the distinctions being highlighted would only be reinforced. By using the more conservative boundary value of $-19.1 \%$, Figure 3 shows the very clear difference between the analyses of bone collagen (an averaged lifetime dietary input) and those of dentine (childhood dietary input) even where a low level of marine consumption may be present.

Individuals who were juveniles at the time of death are circled (Figure 3), with the bone collagen sample that is highlighted as a marine consumer being from a five- to six-year-old child (Walsh et al. 2012). The bone collagen values represent a weighted lifetime dietary average (Hedges et al. 2007), whilst the dentine reflects only childhood. Thus the bulk dentine samples and the juvenile bone (which represents no more than seven years of life) appear to indicate low level marine resource consumption during childhood which is not visible in the adult bone samples. Three of the $\delta^{13} \mathrm{C}$ values are above $-18.0 \%$, indicating a relatively higher level of marine food consumption: all are juveniles. Two are bulk dentine analyses of incompletely formed roots (SUMB-5 and SUMB-11; Figure 5) and are suspected to be from the same individual aged 11.5 to 12.5 years at death. The third is the bone of the five- to six-year-old child. In addition, the $\delta^{13} \mathrm{C}$ values of enamel apatite which derive from the whole diet (i.e. not just protein consumption) in early childhood (Lee-Thorp et al. 1989) range from $-16.7 \%$ to $-14.0 \%$ o (Keefe 2007). The difference between the isotope values obtained from dentine collagen and enamel apatite of each individual tooth ranges from $-5.7 \%$ o to $-2.9 \%$. These differences indicate a dietary range from a fully terrestrial/ $\mathrm{C}_{3}$ based diet through to one with a substantial component of marine animal protein and thus concur with the conclusions drawn from collagen alone (Lee-Thorp et al. 1989; Froehle et al. 2010). Overall, this suggests that marine foods were a significant part of the diet of young children but were no longer detectable in completed tooth roots or adult bone samples.

(C) Antiquity Publications Ltd. 

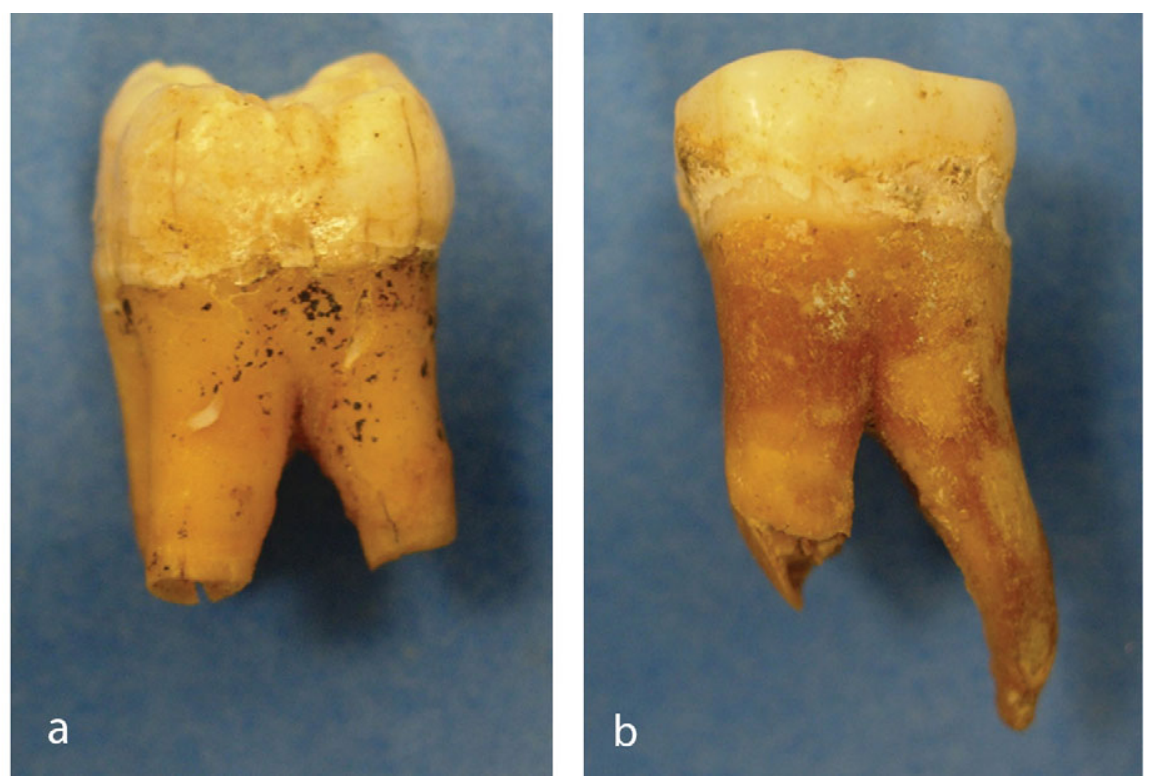

Figure 5. Two of the teeth sampled in this study: (a) SUMB-5 is from a juvenile, 11.5 to 12.5 years of age, and was incompletely formed at death. It has paper-thin root edges; (b) SUMB-12 has completely formed roots, one of which is broken, and is estimated from tooth wear to belong to an adult aged 25-35 years (Table S2).

Did only children eat marine protein? Was childhood-only consumption no longer visible in adult bone collagen due to remodelling? Or were marine foods eaten by both adults and children for short periods of time, such as a period of crop failure, which would not be resolvable in adult bone due to slow bone turnover and lifelong averaging?

\section{Results: incremental dentine samples}

The age-constrained incremental dentine samples provide increased focus to resolve this issue. Figure 6 shows data from three of the eight teeth sampled in this way (the other five are shown in Figure S1). Only one of the eight teeth (SUMB-41) shows a relatively low variation in both $\delta^{13} \mathrm{C}$ and $\delta^{15} \mathrm{~N}$ values that remain within the terrestrial diet range over the first 10 years of life (Figure 6a). For the other seven, the fluctuations have no consistent pattern of chronology or magnitude, although the data for carbon and nitrogen isotopes co-vary at most points and all indicate the likelihood of a period of marine consumption at some time during childhood. The most extreme of the fluctuations is shown for SUMB-42, an individual who survived to adulthood, but between the ages of 7 and 10 appears to have been a high-level marine food consumer (Figure 6b).

For most of the individuals, the relationship between the $\delta^{13} \mathrm{C}$ and $\delta^{15} \mathrm{~N}$ values indicates that these fluctuations do not relate to breastfeeding at a late age as a possible alternative famine strategy. In that case, the $\delta^{13} \mathrm{C}$ values would be expected to be lower given that the (C) Antiquity Publications Ltd. 

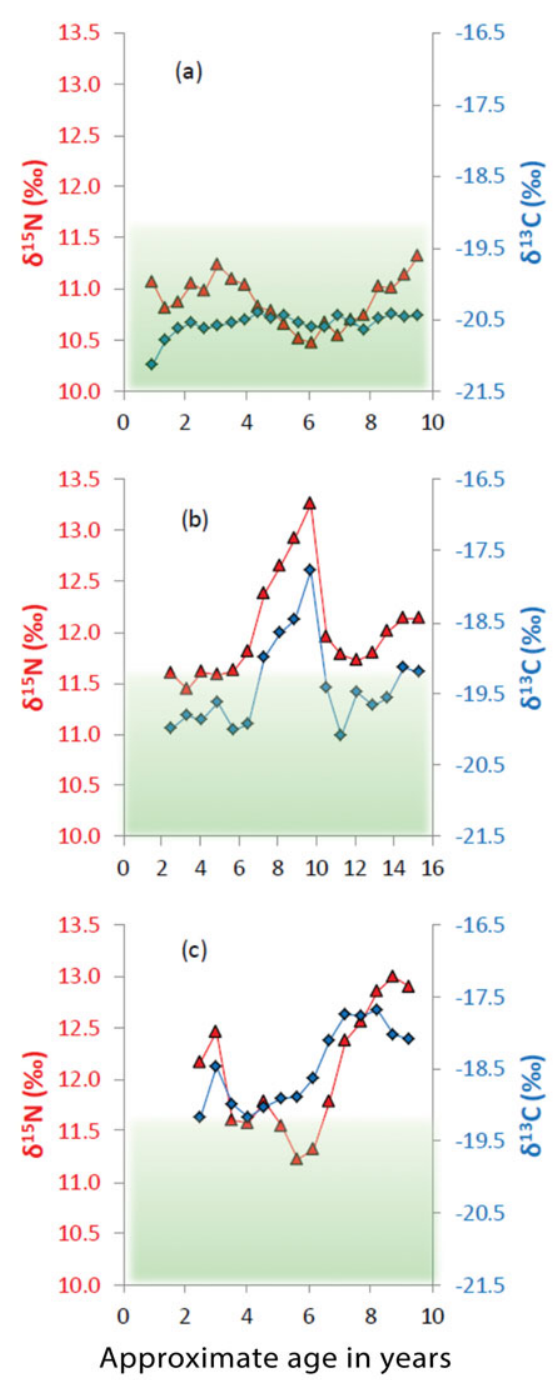

Figure 6. Carbon and nitrogen stable isotope ratios of the incremental dentine samples from a) SUMB-41; b) $S U M B-42$; and c) SUMB-43. The shaded green area at the bottom of each chart represents a mainly terrestrial diet (see supplementary discussion). (a) First molar, age at death 17-25 years, no significant marine component to the diet indicated; (b) second molar, age at death 25-35 years, high level of marine component to the diet indicated at around age 9; (c) second molar, age at death 11.5-12.5 years, high level of marine component to the diet at time of death. Charts for the other five incrementally sampled teeth are available in the online supplementary information. introduction of foods other than breast milk to the diet during the weaning process appears to have a bigger impact on $\delta^{13} \mathrm{C}$ values than on $\delta^{15} \mathrm{~N}$ values (Fuller et al. 2006). The correlation between $\delta^{15} \mathrm{~N}$ and $\delta^{13} \mathrm{C}$, together with the magnitude of the higher $\delta^{15} \mathrm{~N}$ values, also rules out physiological stress as the driver for most of the samples (Mekota et al. 2006). SUMB-44, between the ages of 10 and 16 , does show a combination of relatively high $\delta^{15} \mathrm{~N}$ values with $\delta^{13} \mathrm{C}$ values within the range expected for a terrestrial diet (Figure S1c). This could be explained by the consumption of breast milk at a late age, or freshwater aquatic resources. However, exclusively freshwater fish are unlikely to have been available as there are no native species in the Shetland Islands: today only a few species are established in the lochs and burns of Shetland, and all of them have a salinity tolerance or a marine phase and are thus unlikely to provide the required terrestrial $\delta^{13} \mathrm{C}$ values (Johnston 1999: 116-17; Robson et al. 2012). A further interpretation for SUMB-44 is that the high $\delta^{15} \mathrm{~N}$ values record a period of nutritional or physiological stress (Mekota et al. 2006).

Three of these incrementally sampled teeth may indicate that periods of marine consumption equate with crises which have led to early mortality (SUMB-40, 8.8-9.5 years, Figure S1b; SUMB-43, 11.5-12.5 years, Figure 6c; SUMB-46, 6.5-7 years, Figure S1e). These teeth were incompletely formed at death as is also the case for SUMB-5 (Figure 5). Their three profiles show high $\delta^{15} \mathrm{~N}$ and $\delta^{13} \mathrm{C}$ values at the end of their arrested sequence. In accordance with the bulk root dentine for SUMB-5 and SUMB-11, which was also still forming at death and for which very similar values were obtained, the data suggest that marine foods were an important part of the diet at the end of their lives. 


\section{Conclusions}

Sporadic dietary shifts from terrestrial to marine protein consumption are not visible in adult bone collagen data. That is one reason why there may be an apparent discrepancy between the isotope data for dietary change at the Mesolithic-Neolithic transition and the archaeological evidence, particularly in the form of marine resource remains in middens. Bulk dentine samples suggest a marine input in childhood, but it is the novel high-resolution dentine increments which show that this is extremely unlikely to be long-term, low-level or seasonal supplementation of a terrestrial diet with marine foods. Instead, it is consistent with short-term episodes of high-level consumption at different ages in different individuals. This strategic consumption may be a response to unpredictable environmental crises which led to a shortage of terrestrial foods and possibly, for some children, death. The excavation of the later Neolithic Mound 11 on the Tofts Ness peninsula of Sanday, Orkney, provides evidence of an economy where grain (six-row barley) was harvested early and heavy emphasis was placed on fishing and bird capture; this suggests a site where such periods of shortage occurred (Dockrill \& Bond 2007: 38). Added to this is the question of the contemporary organisation of society and how this might correspond to the social access to the economic resource (Dockrill \& Bond 2007: 381).

The isotope data thus support the continued consumption of marine resources such as seal and seabirds at Sumburgh, as indicated by the archaeological assemblage at this marginal, coastal site, but only as a short-term strategy. It also implies that even at the edge of the Neolithic world, where the establishment of agriculture was difficult and conditions adverse, requiring the use of midden material and organic additives to establish small managed plots for cereal production (Dockrill \& Bond 2009), the Early Neolithic inhabitants of the Shetland Islands were attempting to maintain a terrestrial diet, resorting to marine foods only when necessity demanded. In other words, the 'dietary shift' model at this time holds up even in an environment where marine resources were key to survival. This is an important step forward for understanding the development of the Neolithic in north-west Europe. The increased temporal resolution obtained from incremental dentine sampling brings the lives of ancient people into sharper focus and enables diet in the last few months of life to be ascertained. Attention should now be directed to less marginal, mainstream sites in Britain, Scandinavia and other parts of Europe to investigate whether marine foods were also consumed sporadically in the earliest Neolithic in regions more favourable to agriculture.

\section{Acknowledgements}

Funding for this project was provided by Historic Scotland, the Society of Antiquaries of Scotland, the NERC and the University of Bradford. We are grateful to Carol Christiansen and the late Tommy Watt at Shetland Museum for allowing us to sample the Sumburgh cist burials. Samples were analysed at the Stable Isotope Facility at the University of Bradford and radiocarbon dating was undertaken at the Scottish Universities Environmental Research Centre (SUERC). Deborah Lamb (UHI, Shetland) and Jonathan Swale (Scottish Natural Heritage) collected the modern cockles. We are indebted to Rebecca Nicholson for discussions and advice on the availability of freshwater fish in the Shetland Islands, Peter Montgomery for assistance with figures and Peter Rowley-Conwy and Michael Church, who read and commented on early drafts.

(C) Antiquity Publications Ltd. 


\section{Janet Montgomery et al.}

\section{References}

AlQahtani, S.J., M.P. Hector \& H.M. Liversidge. 2010. The London atlas of human tooth development and eruption. American Journal of Physical Anthropology 142: 481-90.

BAILEY, G. \& N. MiLnER. 2003. Coastal hunter-gatherers and social evolution: marginal or central? Before Farming 3-4: 1-15.

Beaumont, J., A. Gledhill, J. Lee-Thorp \& J. MonTGOMERY. 2013. Childhood diet: a closer examination of the evidence from dental tissues using stable isotope analysis of incremental human dentine. Archaeometry 55: 277-95.

Birnie, J., J. Gordon, K. Bennett \& A. Hall (ed.). 1993. The Quaternary of Shetland. Cambridge: Quaternary Research Association.

Bonsall, C., G.T. Cook, C. Pickard, K. McSweeney \& L. BARTOSIEWICZ. 2009. Dietary trends at the Mesolithic-Neolithic transition in northwest Europe, in P. Crombé, M. Van Strydonck, J. Sergant, M. Boudin \& M. Bats (ed.) Chronology and evolution in the Mesolithic of northwest Europe: 539-62. Newcastle upon Tyne: Cambridge Scholars.

DOCKRILL, S.J \& J.M. BOND. 2007. Investigations in Sanday, Orkney. Vol. 2: Tofts Ness, Sanday. An island landscape through three thousand years of prehistory. Kirkwall: The Orcadian \& Historic Scotland.

-2009 . Sustainability and resilience in prehistoric North Atlantic Britain: the importance of a mixed palaeoeconomic system. Journal of the North Atlantic 2: 33-50.

Eriksson, G., A. Linderholm, E. Fornander, M. Kanstrup, P. Schoultz, H. Olofsson \& K. LIDÉN. 2008. Same island, different diet: cultural evolution of food practice on Öland, Sweden, from the Mesolithic to the Roman period. Journal of Anthropological Archaeology 27: 520-43.

Fischer, A., J. Olsen, M. Richards, J. Heinemeier, A.E. SveinbjörnsdótTir \& P. Bennike. 2007. Coast-inland mobility and diet in the Danish Mesolithic and Neolithic: evidence from stable isotope values of humans and dogs. Journal of Archaeological Science 34: 2125-50.

Froehle, A.W., C.M. Kellner \& M.J. Schoeninger. 2010. FOCUS: effect of diet and protein source on carbon stable isotope ratios in collagen: follow up to Warinner and Tuross (2009). Journal of Archaeological Science 37: 2662-70.

Fuller, B.T., M.P. Richards \& S.A. MAYS. 2003. Stable carbon and nitrogen isotope variations in tooth dentine serial sections from Wharram Percy. Journal of Archaeological Science 30: 1673-84.
Fuller, B.T., J.L. Fuller, D.A. Harris \& R.E.M. HeDGES. 2006. Detection of breastfeeding and weaning in modern human infants with carbon and nitrogen stable isotope ratios. American Journal of Physical Anthropology 129: 279-93.

Gillmore, G.K. \& N. Melton. 2011. Early Neolithic sands at West Voe, Shetland Islands: implications for human settlement, in L. Wilson (ed.) Human interactions with the geosphere: the geoarchaeological perspective: 69-83. London: Geological Society of London.

Gustafson, G. 1950. Age determination on teeth. Journal of the American Dental Association 41: 45-54.

HedGes, R.E.M. 2004. Isotopes and red herrings: comments on Milner $e t$ al. and Lidén $e t a l$. Antiquity 78: 34-37.

Hedges, J.W. \& G.W. Parry. 1980. A Neolithic multiple burial at Sumburgh Airport, Shetland. Glasgow Archaeological Journal 7: 15-26.

Hedges, R.E.M., J.G. Clement, C.D.L. Thomas \& T.C. O'ConNell. 2007. Collagen turnover in the adult femoral mid-shaft: modeled from anthropogenic radiocarbon tracer measurements. American Journal of Physical Anthropology 133: 808-16.

Hillson, S. 2005. Teeth. Cambridge: Cambridge University Press.

Johnston, J.L. 1999. A naturalist's Shetland. London: T. \& A.D. Poyser.

KeEFE, K. 2007. A stable isotope analysis of the Early Neolithic humans interred in the Sumburgh cist, Shetland. Unpublished MSc dissertation, University of Bradford.

LEE-THORP, J.A. 2008. On isotopes and old bones. Archaeometry 50: 925-50.

LeE-Thorp, J., J.C. SeAly \& N.J. VAN DER MERWE. 1989. Stable carbon isotope ratio differences between bone collagen and bone apatite, and their relationship to diet. Journal of Archaeological Science 16: 585-99.

Lubell, D., M. JaCKes, H. SchWarcz, M. KnyF \& C. MeIKLEJOHN. 1994. The Mesolithic-Neolithic transition in Portugal: isotopic and dental evidence of diet. Journal of Archaeological Science 21: 201-16.

Mekota, A.-M., G. Grupe, S. Ufer \& U. Cuntz. 2006. Serial analysis of stable nitrogen and carbon isotopes in hair: monitoring starvation and recovery phases of patients suffering from anorexia nervosa. Rapid Communication in Mass Spectrometry 20: 1604-10.

Melton, N.D. 2008. West Voe: a Mesolithic-Neolithic transition site in Shetland, in G. Noble, T. Poller, J. Raven \& L. Verrill (ed.) Scottish odysseys: the archaeology of islands: 23-36. Stroud: Tempus. 


\section{Strategic and sporadic marine consumption at the onset of the Neolithic}

- 2009. Shells, seals and ceramics: an evaluation of a midden at West Voe, Sumburgh, Shetland, 2004-2005, in S. McCartan, P. Woodman, R. Schulting \& G. Warren (ed.) Mesolithic horizons: papers presented at the Seventh International Conference on the Mesolithic in Europe, Belfast 2005: 184-89. Oxford: Oxbow.

Melton, N.D. \& R.A. Nicholson. 2004. The Mesolithic in the Northern Isles: the preliminary evaluation of an oyster midden at West Voe, Sumburgh, Shetland, UK. Antiquity 78. Available at http://www.antiquity.ac.uk/projgall/nicholson299/ (accessed 3 May 2013).

- 2007. A Late Mesolithic-Early Neolithic midden at West Voe, Shetland, in N. Milner, O.E. Craig \& G.N. Bailey (ed.) Shell middens in Atlantic Europe: 94-100. Oxford: Oxbow.

Milner, N., O.E. Craig, G.N. Bailey, K. Pedersen \& S.H. ANDERSEN. 2004. Something fishy in the Neolithic? A re-evaluation of stable isotope analysis of Mesolithic and Neolithic coastal populations. Antiquity 78: 9-22.

Nanci, A. (ed.). 2003. Ten Cate's oral histology: development structure and function. St. Louis (MO): Mosby.

Richards, M.P. \& P.A. Mellars. 1998. Stable isotopes and the seasonality of the Oronsay middens. Antiquity 72: 178-84.

Richards, M.P. \& R.J. SCHulting. 2006. Against the grain? A response to Milner et al. (2004). Antiquity 80: 444-56.

Richards, M.P., R.J. SCHULTING \& R.E.M. HEDGES. 2003. Sharp shift in diet at onset of Neolithic. Nature 425: 366.

Robson, H., S. Andersen, O.E. Craig, A. Fischer, A. Glykou, S. Hartz, H. LÜbKe, U. SCHMÖlCKE \& C. Heron. 2012. Carbon and nitrogen isotope signals in eel bone collagen from Mesolithic and Neolithic sites in northern Europe. Journal of Archaeological Science 39: 2003-11.

ROWLES, S.L. 1967. Chemistry of the mineral phase of dentine, in A.E.W. Miles (ed.) Structural and chemical organization of teeth: 201-45. London: Academic.
SChulting, R.J. \& M.P. Richards. 2002. The wet, the wild and the domesticated: the Mesolithic-Neolithic transition on the west coast of Scotland. European Journal of Archaeology 5: 147-89.

- 2009. Radiocarbon dates and stable isotope values on human remains, in A. Ritchie (ed.) On the fringe of Neolithic Europe. Excavation of a chambered cairn on the Holm of Papa Westray, Orkney: 67-74. Edinburgh: Society of Antiquaries of Scotland.

Schulting, R., A. Sheridan, R. Crozier \& E. MurPHY. 2010. Revisiting Quanterness: new AMS dates and stable isotope data from an Orcadian chamber tomb. Proceedings of the Society of Antiquaries of Scotland 140: 1-50.

SHERIDAN, A. 2012. Neolithic Shetland: a view from the 'mainland', in D.L. Mahler (ed.) The border of farming and the cultural markers: 6-36. Copenhagen: National Museum of Denmark.

Smits, E., A.R. Millard, G. Nowell \& D.G. PEARSON. 2010. Isotopic investigation of diet and residential mobility in the Neolithic of the Lower Rhine Basin. European Journal of Archaeology 13: 5-31.

TAuber, H. $1981 .{ }^{13} \mathrm{C}$ evidence for dietary habits of prehistoric man in Denmark. Nature 292: 332-33.

VAN KLINKEN, G.J. 1999. Bone collagen quality indicators for palaeodietary and radiocarbon measurements. Journal of Archaeological Science 26: 687-95.

VAN RENSBURG, B.G.J. 1987. Secondary dentine-cause and effect. Journal of Dental Research 66: 949.

VEIS, A. 1989. Biochemical studies of vertebrate tooth mineralization, in S. Mann, J. Webb and R.J.P. Williams (ed.) Biomineralization: chemical and biochemical perspectives: 189-222. New York: VCH.

Walsh, S.L., C.J. KNÜsel \& N.D. Melton. 2012. A re-appraisal of the Early Neolithic human remains excavated at Sumburgh, Shetland in 1977. Proceedings of the Society of Antiquaries of Scotland: 141: 3-17.

Received: 17 October 2012; Accepted: 6 December 2012; Revised: 4 February 2013

(C) Antiquity Publications Ltd. 